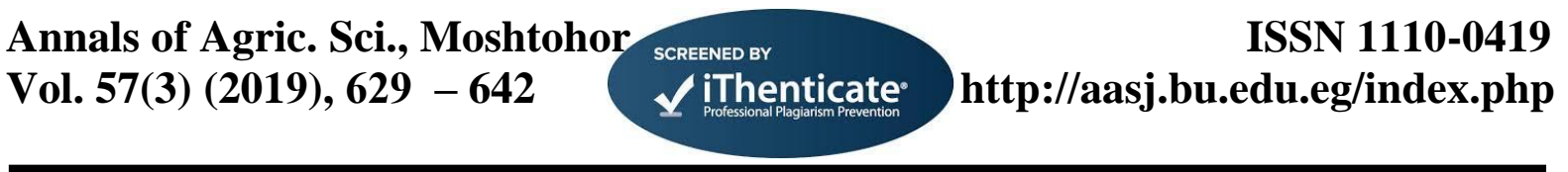

\title{
Determination Critical Period of Weed Competition and Their Control Method in Carrot Yield (Daucus Carota L) With Economic Feasibility
}

\author{
Fadlallah, A. M. Abd El-kareem, A. M. Sharshar, A.A.H. \\ Central Laboratory for Weed Research, Giza, Egypt. \\ Corresponding author: Ashraf451967@yahoo.com
}

\begin{abstract}
Four field experiments were conducted at Horticulture Research Station, El-Kanater El-Khiria, Kalubia governorate in two successive winter seasons 2016/17 and 2017/18. First, two of them were carried out to determine the period required for weed free maintenance after carrot sowing to produce the maximum yield and the long of weed competition period which can be allowed without reduction in the yield .Each experiment contained twelve treatments i.e six weed free periods at 2, 4, 6, 8 and 10 weeks after sowing and for the whole season and six treatments of weed competition period at 2, 4, 6,8 and 10 weeks from sowing and for the whole season. Second, of them two field experiments were carried out to evaluate the efficacy of some promising pre emergence soil acting herbicides on weeds and root yield of carrot. Each experiment including seven weed control treatments namely hand weeding at twice, metribuzin at the rate of $100 \mathrm{~g} / \mathrm{fed}$., linuron at the rate $0 f 500 \mathrm{~cm}^{3} / \mathrm{fed}$., pendimethalin at rate 1.7 liter /fed., butralin at rate. 2.5 liter/fed., as post sowing pre- emergence, prometryn the rate of 1.25 liter./fed. as post sowing and well as the unweeded treatment. The main findings showed that weed infestation for whole season reduced yield of carrot per fed. by 47.1 and $47.0 \%$ in both seasons, respectively, than weed free for whole season treatment. Mathematized models which given the relationship between weed infestation periods and carrot yield show that quadratic equation was the best model to predict yield losses due to weed competition is showing that the critical periods length of weed competition nine weeks period from sowing which is required to be eliminates to obtain the maximum carrot yield of carrot without reduction. Weed free for all season gave the best value for all characters per faddan. In the second study, results show that the use of linuron at the rate of 500 $\mathrm{cm} 3 /$ fad gave the highest controlling percentages of the annual broad leaf and grassy weeds through this period with the highest values of carrot yield and can be advised for weed control in mentioned critical period of carrot. At harvest there is no herbicides residues were detected in the edible carrot yield.
\end{abstract}

Key words: Herbicides - hand hoeing - residues- critical period.

\section{Introduction}

Carrot crop is grown in Egypt in 16586 faddan with an average of $12.7 \mathrm{ton} /$ faddan in 2016/2017 season which are used for local consumption. Weeds are permanent constraint to vegetables which face carrot crop growers which can be considered as poor competitor for weeds to nutrients, water, light and space. Uptill now little information in Egypt about the nature of weeds competition or registered herbicide to invoke weed problem in carrot. Earlier definition about the critical period of weed competition was suggested by Nieto et. al (1968) It has been defined as the period which weeds much controlled to prevent yield losses. It has been used to determine the period when control operation should be carried out to minimize yield losses for many crops Zimdahl (1988). An estimation of the critical period of weed control is helpful in formulating appropriate weed control strategies. A regression approach can be used to estimate the thresholds of critical period of weed control, while, yields were a linear, quadratic and logistic functions duration of weed free and infested periods(Singh et al 1996). Understanding of critical period of weed control is one of the most important tool in integrated weed management (Swanton and Weise 1991). The critical period of weed competition has been defined as the time interval between the maximum weed - infested period, or the length of time that weeds which emerge with the crop can remain uncontrolled before the begin to compete the crop and cause yield loss, and the minimum weed free period, or the length of time that the crop must be free from weed after emergence ( Kropf et al 1993).. In abroad some researchers found that the presence of weed in carrot fields throughout the whole season can cause yield losses varied from 94 to $96 \%$ and the field should be free from weeds between 19-60 days after crop emergence, Coelho et.al.(2009), Freitas et. al. (2009), Mena et al (1978) and Moenandir (1987). The programmer for weed control in carrot through the critical period can include some early pre emergence herbicides belonged to dinitroaniline derivatives as pendimethalin and butralin or triazine derivatives as prometryn and metribuzin which applied at two weeks after sowing or substituted urea herbicides as linuron which mentioned by researches as Bakhshish Singh et al (2010), ), Farag et nal (2001), Kavaliauskaite (2009), Montemurro and Bianco (1977 and Richardson et al (1979) found that very good results on controlling weeds with the use of linuron at $2 \mathrm{~kg} / \mathrm{ha}$. as pre-em. and butralin gave selective control of annual grasses and some broadleaved weeds. Pendimethalin at $0.375,0.562$ and 
$0.750 \mathrm{~kg}$ ha and, two hand hoeing (20 and 40 days after sowing) reduced the weed dry matter accumulation significantly as compared to unweeded control. The season long weed competition reduced the carrot root yield from 11.5 to 26.1 percent as compared to unweeded check. Also, herbicides residues in carrot root should be in minimal cases. Field trials were carried out in carrot crop to investigate herbicides prometryn, metribuzin, linuron reduced the total amount of weeds in carrot crop. The least efficient was prometryn $(3.0 \mathrm{~L} \mathrm{ha})$ when sprayed separately after sowing where the amount of weeds when reduced by $62 \%$. The efficiency of metribuzin was higher when it was sprayed single $(0.5 \mathrm{~L} \mathrm{ha})$ at carrot 1-2 leaves stage where the amount of weeds was reduced by $84 \%$. The highest amount of weeds was killed when linuron was applied separately $(1.0 \mathrm{~L} \mathrm{ha})$ after sowing which weeds were reduced by $94 \%$ .Comprising trifluralin, pendimethalin and linuron each used at $0.75,1.00$ and $1.25 \mathrm{~kg} / \mathrm{ha}$ and each at 0.75 $\mathrm{kg} / \mathrm{ha}$ +hand weeding, were compared with three hand weeding at 20, 40 and 60 DAS as well as season-long weed-free and unweeded conditions significantly reduced total weed population and weed dry weight compared with weedy control. The extent of weed problem and available methods of control in carrot is our interest in this study. Thus, the objective of this research is firstly, to determine the magnitude of weed/carrot competition and when start and to be stopped and determine mathematical model which given these relationships and secondly, to find out the proper herbicidal treatments to control weeds which infest carrot fields through weed control should start and to be stopped without residues in carrot tissues.

\section{Materials and Methods}

The present work consisted of two studies were carried out at the Horticulture Research Station, ElKanater El-Khiria, Kalubia governorate throughout $2016 / 17$ to $2017 / 18$ successive winter seasons in clay soil. Toketa variety was used in these experiments

The main physical and chemical properties in experimental soil were determined according to Jackson (1967) and Piper (1950) and were presented in Table (1).

Table 1. Physical and chemical analysis of the soil of carrot at $(0-30 \mathrm{~cm}$ depth).

\begin{tabular}{|c|c|c|c|c|c|c|c|c|c|}
\hline \multicolumn{10}{|c|}{ Particle size distribution } \\
\hline \multicolumn{2}{|c|}{ Sand \% } & \multicolumn{2}{|l|}{ Silt \% } & \multicolumn{3}{|c|}{ Clay \% } & \multicolumn{2}{|c|}{ Soil texture } & Organic matter \% \\
\hline & & 22.74 & & \multicolumn{3}{|c|}{46.59} & \multicolumn{2}{|c|}{ Clay } & $\begin{array}{c}2.1 \\
\end{array}$ \\
\hline \multicolumn{10}{|c|}{ Chemical properties } \\
\hline $\mathrm{SO}_{4}{ }^{2-}$ & $\mathrm{Cl}^{-}$ & $\mathrm{HCO}^{3-}$ & $\mathrm{CO}_{3}{ }^{2-}$ & $\mathbf{K}^{+}$ & $\mathrm{Na}^{+}$ & $\mathrm{Mg}^{2+}$ & $\mathrm{Ca}^{2+}$ & Ec. ds/m & $\begin{array}{c}\text { pH } \\
(1: 2.5)\end{array}$ \\
\hline 0.51 & $\mathbf{0 . 5 0}$ & $\mathbf{0 . 8 9}$ & $\mathbf{0 . 0 0}$ & 0.6 & 0.7 & 0.34 & 0.26 & 0.19 & 8.30 \\
\hline
\end{tabular}

\section{I- First study: Estimation of critical periods of weed competition.}

Two field experiments were conducted in 2016/17 and 2017/18 winter seasons were designed complete randomized block design with four replicate in twelve varying of weed competitions and weed-free intervals to determine the critical period and magnitude of losses of carrot yield due to weed competition at these intervals follows as:

1 - Weed free for the whole season.

2- Weed free for 2 weeks from sowing.

3 - Weed free for 4 weeks from sowing.

4- Weed free for 6 weeks from sowing.

5 - Weed free for 8 weeks from sowing.

6- Weed free for 10 weeks from sowing.

In these treatments the crop is kept free from the weeds from sowing until certain time after which weeds were allowed to grow

7- Weed competition for the whole season.

8- Weed competition for 2 weeks from sowing.

9 - Weed competition for 4 weeks from sowing.

10- Weed competition for 6 weeks from sowing.

11- Weed competition for 8 weeks from sowing.

12- Weed competition for 10 weeks from sowing.
In these treatments, weeds are allowed to grow from the beginning to certain time, after which they are removed until the end of the growth cycle

The agriculture practices i.e., fertilization; irrigations; pest and diseases control were managed in accordance with local recommendations. The soil texture of the experiments sites was clayey with $\mathrm{PH}$ 8.03 .

The treatments were arranged in randomized complete block design with four replicates. The plot area was $10.5 \mathrm{~m} 2$ (3.5 m length $\mathrm{x} 3 \mathrm{~m}$ width). Four kg/ fed. from Toketa hybrid use in this study and the seed were sowing in 02/10/2016 and 03/10/2017 and both harvested at the third weeks of February

In these two field experiments, the following data were recorded as follows:

\section{A- Weed assessment:-}

A random sample was taken from one $\mathrm{m}^{2}$ from each plot at the end of the competition treatments. The sample was classified into grassy and broad- leaves weeds and dried in oven $70{ }^{\circ} \mathrm{C}$ until constant weights then the dried weeds were weighed.

\section{B- Growth characters and root carrot yield:-}

Sample of ten plants were pulled at harvest from each plot to estimated:

1- Plant height $(\mathrm{cm})$. 
2- Number of leaves/plant.

3- Root diameter $(\mathrm{cm})$.

4- Root weight head (g.).

5- Root Length of head $(\mathrm{cm})$.

6- Root Yield $\mathrm{t} / \mathrm{fed}$. was determined from the whole plants of each plot (1/400 fed.).

C- Estimation critical weed control period:

Data of each season were statistically analyzed according to the procedures outlined and the means were compared by least significant differences (L.S.D. at $5 \%$ ) by (Gomez and Gomez 1984). Actual yield was subjected to analysis of variance using Regression Curve Estimation Functions to analysis of Statistical Procedure for Social Sciences (SPSS 12.0 for windows) (Norsworthy and Oliveira, 2004). Also, logistic regression model is presented in (Agresti 1996).

* Linear model is estimated using the formula:

$$
\mathrm{Y}=\mathrm{a}+\mathrm{bx}
$$

Where: $Y=$ is the yield/fed. in ton.

$\mathrm{a}:$ is the $\mathrm{Y}$ intercept.

$\mathrm{b}:$ is the linear coefficient of regression.

$\mathrm{x}:$ is the duration of applied weed-free or weed- competition periods.

* Quadratic polynomial model is computed using the formula:

$$
Y=a+b x+c x^{2}
$$

Where: $Y=$ is the yield/fed. in ton.

$\mathrm{a}:$ is the $\mathrm{Y}$ intercept.

$\mathrm{b}:$ is the linear coefficient of regression.

$\mathrm{c}:$ is the quadratic coefficient of regression.

$\mathrm{X}$ : is the duration of applied weed-free or weedcompetition periods.

(Neter et al., 1990)

* Logistic regression equation is computed using the formula:

$$
Y=\frac{A+C}{1+e-B(t-m)}
$$

Where: $\quad \mathrm{Y}=$ is the yield/fed. in ton.

$\mathrm{A}=$ is asymptotic yield depending on whether $\mathrm{B}$ is negative or positive

$\mathrm{B}=$ is the shape parameter of the regression of yield.

$\mathrm{C}=$ is twice the difference of yield at the point of inflection and the asymptotic yield.

$\mathrm{M}=$ is the point of inflection of logistic curve.

$\mathrm{t}=\mathrm{is}$ duration of weed infested or weed free peroids

(Hall et al., 1992) and modified by (Knezevic et al., 2003)

\section{II-Second study: Weed control treatments.}

Two field experiments were conducted at 2016/17 and 2017/18 winter seasons to evaluate efficiency of seven weed control treatments on controlling the annual grassy and broad leaf weeds and their reflection on root carrot yield and its components as well as their herbicides residue on root

Each experiment included seven weed control treatments as follows:
1- Metribuzin (4-amino-6-(1,1-dimethylethyl)-3(methylthio)1,2,4-triazip-5 (4H ) one) known commercially as Sencor $70 \%$ WP was applied at the rate of $100 \mathrm{~g} / \mathrm{fed}$. as post-sowing immediately after sowing .

2- Linuron ( N-(3,4- dichlorophenyl) -N-methoxy$\mathrm{N}$-methylurea) known commercially as Ultra afalon $45 \%$ SC was applied at the rate of 500 $\mathrm{cm}^{3} /$ fed. as post -sowing immediately after sowing.

3- Pendimethalin (N-(1- ethylpropyl) - 3,4 dimethyl2,6 dinitrobenzenamin) known commercially as Stomp extra $45.5 \%$ CS was applied at rate 1.7 liter /fad. as post -sowing immediately after sowing.

4- Butralin(4-(1,1-dimethylethyl)-N-(1methylpropyl) -2,6-dinitrobenzenamine) known commercially as Amex $48 \%$ EC, was applied at rate 2.5 liter/fed. as post -sowing immediately after sowing.

5- Prometryn (N,N-bis (1- methylethyl)-6(methylthio)- 1,3,5- triazine-2,4 diamine) known commercially as Gesagard $70 \% \mathrm{WP}$ was applied at the rate of 1.251 ./fed. after 21 days from sowing

6- hand weeding at two times with 15 days intervals, and beginning at 18 days of sowing.

7- Unweeded check (control).

All herbicidal treatments were sprayed with knapsack sprayer CP3 with 200 liter water/fed. The agriculture practices i.e., fertilization; irrigations; pest and diseases control were managed in accordance with local recommendations.

The treatments were arranged in randomized complete block design with four replicates. The plot area was $10.5 \mathrm{~m} 2$ (3.5 m length $\mathrm{x} 3 \mathrm{~m}$ width). Four kg/ fed. from Toketa hybrid use in this study and the seed were sowing in 02/10/2016 and 03/10/2017 and both harvested at the third weeks of February

The following data were recorded as follows:

\section{A- Weed assessment:-}

A random sample was taken from one $\mathrm{m}^{2}$ from each plot after one month from the last treatment. The sample was classified to grassy and broad- leaves weeds and dried in oven $70{ }^{\circ} \mathrm{C}$ until constant weights then the dried weeds were weighted.

\section{B- Growth characters and carrot yield:-}

Sample of ten plants were taken at harvest and the following data were record.

1- 1-Plant height $(\mathrm{cm})$.

2-Number of leaves/plant.

3-Root diameter (cm).

4- Root weight head (g.).

5- Root Length of head $(\mathrm{cm})$.

6- Root Yield t/fed., was determined from the whole plants of each plot (1/400 fed.).

\section{C- Herbicide residues:}

The herbicides residues for Amex (butralin), Stomp(Pendimethalin), sencor (metribuzin ), Ultra 
afalon (linuron) and Gesagard (Prometryn)s in carrot leaves were analyzed by using the gas liquid Chromatography according to Nguyen et. al. (2008).

\section{D - Economic feasibility study.}

Economic evaluation due to weed control treatments was calculated according to Heady and Dillon (1961) as follows:

Gross income (LE) = yield (ton/ fed.) $\mathrm{x}$ price of ton (LE). Gross margin $(\mathrm{LE})=$ gross income - total cost $(\mathrm{LE})$.

Benefit $/$ cost ratio $=$ gross income $/$ total cost .

\section{F- Statistical analysis:-}

Mean values of each experiment were subjected to the analysis of variance to test the significance as described by Gomez and Gomez (1984). Duncan means separation test and correlation were detected by using Mstat C ver. 4 software (Mstat 1985).

\section{Results and Discussion}

First study: Effect of weed competition treatments on weeds and carrot yield and its components.

\section{a. On weeds.}

It was noticed that the experimental soil in the two seasons was moderately infested by both grassy and broadleaf weeds species. The weed species included Portulaca oleracea L.; Sonchus oleraceus L.; Chenopodum album L.; Bidens bipinnata L.; Amaranthus ascendenss lois; Xanthium strumarium L.. and Malva parviflora L. as annual broad-leaved weeds with infestation rates 0.98 and 1.39 ton dry weight ./fed in first and second seasons, respectively. Meanwhile, Echinochloa colonum L.; Brachiaria reptans L.; Phalaris minor L. and Setaria viridis L . as annual grassy weeds with infestation rate of 0.46 and 0.65 ton dry weight ./fed. in first and second seasons, respectively.

Grassy, broadleaf weeds and their total dry weight. decreased and root yield increased as the duration of weed free period increased. In contrast, was happened as the duration of weed infested period increased.

Results in Table (2) show significant decreases in the dry weight of the two categories of annual weeds by all weed competition treatments in both seasons. Weed free for the whole season gave the highest reduction percentage in the dry weight of the broadleaf weeds, grassy weeds and their total by 95.7 .97 .7 and $97.1 \%$ and $94.6,94.2$ and $94.3 \%$ ,respectively in the first and second seasons followed by weed free for ten weeks by 91.2, 95.6 and 94.2 and 91.2, 93.1 and $92.5 \%$,respectively, in the first and second seasons. However, weed competition for two weeks reached in nearly to weed free ten weeks. in both seasons followed by weed com[petition for four weeks. in the first season only compared with weed competition for the whole season. The increasing intervals of weeds removal (weed free) resulted in a gradual decrease in the weight of the remaining weeds until the ten weeks which reaches in nearly to the weed free for the whole season.

Table 2. Effect of weed competition treatments on dry weight of grassy, broadleaf and total annual weeds $(\mathrm{g} / \mathrm{m} 2)$ during 2016//17 and 2017/18 seasons.

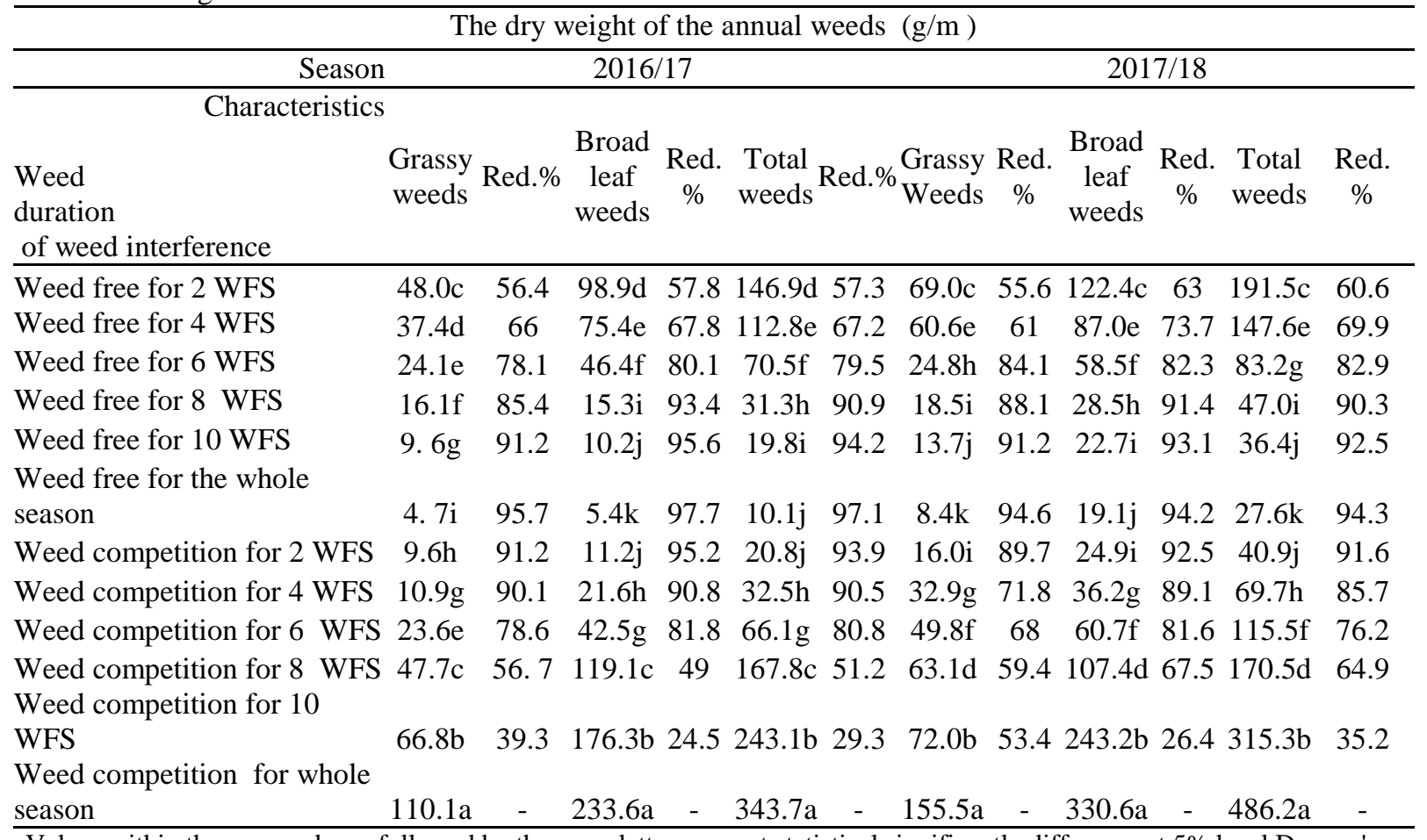

Values within the same column followed by the same letters are not statistical significantly difference at $5 \%$ level Duncan's multiple range test 


\section{b - On carrot yield and its component}

Results in table (3) show that all weed free and weed infested periods gave significant values on plant growth characteristics, root yield of carrot and its components, except with weed competition for ten weeks from sowing for root yield of carrot in the first season only compared to the weed competition for the whole growth cycle in both seasons Weed free for the whole season gave the highest increasing percentage in No. of leaves /plant, plant height $(\mathrm{cm})$, root length $(\mathrm{cm})$, root diameter $(\mathrm{cm})$, root weight $(\mathrm{g})$ and root yield (t./fed.) with132.5, 175.6, 113.5, 182.4, 922.8 and $89.1 \%$,respectively. The following increasing percentage were obtained by weed free for ten weeks from sowing by 90.9, 106.7, 147.1, , 668.4 and $79.3 \%$,. Whilst, weed competition for two weeks. from sowing gave increasing percentage of the pervious respective characteristics with 83.9, 118.0, $78.8,152.9,252.2$ and $57.2 \%$,respectively and weed competition for four weeks. from sowing gave increasing percentage with $73.4,76.7,68.3,129.4$, 181.6 and $37.8 \%$, respectively compared with the weed competition for the whole season in the first season. The same results approximately were obtained in the second season. These results agree with (Freitas et. al. (2009) they found that the critical periods of weed interference prevention (CPWIP) were from 19 to 36 days after crop emergence, respectively. Weed interference throughout the crop cycle reduced crop yield up to $96 \%$.

Table 3. Effect of weed competition treatments on carrot yield and its components at harvest during 2016//17 and 2017/18 seasons

\begin{tabular}{|c|c|c|c|c|c|c|c|}
\hline $\begin{array}{l}\text { Weed duration of } \\
\text { weed interference }\end{array}$ & $\begin{array}{l}\text { No. of leaves } \\
\text { /plant }\end{array}$ & $\begin{array}{c}\text { Plant } \\
\text { height } \\
(\mathbf{c m})\end{array}$ & $\begin{array}{c}\text { Root } \\
\text { length } \\
(\mathrm{cm})\end{array}$ & $\begin{array}{c}\text { Root } \\
\text { diameter } \\
(\mathbf{c m})\end{array}$ & $\begin{array}{c}\text { Root } \\
\text { weight } \\
\text { (g) }\end{array}$ & $\begin{array}{l}\text { Root } \\
\text { Yield } \\
(\text { t/fed })\end{array}$ & $\begin{array}{c}\text { Reductio } \\
\text { n yield } \\
\% \text { from } \\
\text { weed } \\
\text { free } \\
\end{array}$ \\
\hline & \multicolumn{7}{|c|}{ 2016/17 season } \\
\hline Weed Weed free for 2 WFS & $5.87 f$ & $25.3 \mathrm{i}$ & $14.8 \mathrm{f}$ & $1.93 \mathrm{~h}$ & $29.2 \mathrm{fg}$ & $8.77 \mathrm{f}$ & 27.9 \\
\hline Weed free for 4 WFS & $7.00 \mathrm{e}$ & $32.6 f$ & $17.9 \mathrm{~cd}$ & $2.3 \mathrm{~g}$ & $38.2 \mathrm{e}$ & $9.52 \mathrm{e}$ & 21.7 \\
\hline Weed free for 6 WFS & $7.77 \mathrm{~d}$ & $37.4 \mathrm{~d}$ & $18.6 \mathrm{bc}$ & $3.5 \mathrm{e}$ & $50.4 \mathrm{~d}$ & 9.81de & 19.3 \\
\hline Weed free for 8 WFS & $8.03 \mathrm{~d}$ & $44.1 \mathrm{c}$ & $19.3 b$ & $4.0 \mathrm{~cd}$ & $60.5 \mathrm{c}$ & $10.52 \mathrm{c}$ & 13.5 \\
\hline Weed free for 10 WFS & $9.03 b$ & $52.6 b$ & $21.5 \mathrm{a}$ & $4.2 \mathrm{bc}$ & $87.6 b$ & $11.53 b$ & 5.2 \\
\hline Weed free for whole season & $11.00 \mathrm{a}$ & $56.5 \mathrm{a}$ & $22.2 \mathrm{a}$ & $4.8 \mathrm{a}$ & $116.6 \mathrm{a}$ & $12.16 \mathrm{a}$ & - \\
\hline Weed competition for 2 WFS & $8.70 b c$ & $44.7 \mathrm{c}$ & $18.6 \mathrm{bc}$ & $4.3 b$ & $40.2 \mathrm{e}$ & $10.11 d$ & 16.9 \\
\hline Weed competition for 4 WFS & $8.20 \mathrm{~cd}$ & $35.0 \mathrm{e}$ & $17.5 \mathrm{~d}$ & $3.9 \mathrm{~d}$ & $32.1 \mathrm{f}$ & $8.86 f$ & 27.1 \\
\hline Weed competition for 6 WFS & $6.70 \mathrm{e}$ & $30.2 \mathrm{~g}$ & $15.8 \mathrm{e}$ & $3.4 \mathrm{e}$ & $25.9 \mathrm{gh}$ & $7.91 \mathrm{~g}$ & 35 \\
\hline Weed competition for 8 WFS & $5.90 \mathrm{f}$ & $27.3 \mathrm{~h}$ & $13.7 \mathrm{~g}$ & $2.8 \mathrm{f}$ & $24.2 \mathrm{~h}$ & $7.21 \mathrm{~h}$ & 40.7 \\
\hline Weed competition for 10 WFS & $5.40 \mathrm{f}$ & $21.7 \mathrm{j}$ & $12.9 \mathrm{~h}$ & $2.4 \mathrm{~g}$ & $15.9 \mathrm{i}$ & $6.76 \mathrm{i}$ & 42.9 \\
\hline \multirow[t]{2}{*}{ Weed competition for whole season } & $4.73 \mathrm{~g}$ & $20.5 \mathrm{j}$ & $10.4 \mathrm{i}$ & $1.7 \mathrm{i}$ & $11.4 \mathrm{j}$ & $6.43 \mathrm{i}$ & 47.1 \\
\hline & \multicolumn{6}{|c|}{$2017 / 18$ season } & \\
\hline Weed Weed free for 2 WFS & $5.60 \mathrm{e}$ & $27.1 \mathrm{~h}$ & $13.3 \mathrm{i}$ & $1.87 \mathrm{~h}$ & $22.10 \mathrm{~h}$ & $8.59 \mathrm{f}$ & 25.4 \\
\hline Weed free for 4 WFS & $6.73 d$ & $35.8 \mathrm{f}$ & $16.6 f$ & $2.10 \mathrm{~h}$ & $32.00 f$ & $9.01 \mathrm{e}$ & 21.8 \\
\hline Weed free for $6 \mathrm{WFS}$ & $7.37 \mathrm{c}$ & $37.9 \mathrm{e}$ & $17.4 \mathrm{~d}$ & $3.20 \mathrm{e}$ & $43.10 \mathrm{~d}$ & $9.30 \mathrm{~d}$ & 19.3 \\
\hline Weed free for 8 WFS & $7.77 \mathrm{c}$ & $47.7 \mathrm{~d}$ & $18.1 \mathrm{c}$ & $3.77 \mathrm{~cd}$ & $51.03 \mathrm{c}$ & $9.84 \mathrm{c}$ & 14.6 \\
\hline Weed free for 10 WFS & $8.60 \mathrm{~b}$ & $54.5 b$ & $21.9 \mathrm{~b}$ & $3.97 b c$ & $81.93 b$ & $10.76 b$ & 6.6 \\
\hline Weed free for whole season & $10.80 \mathrm{a}$ & $60.2 \mathrm{a}$ & $20.5 \mathrm{a}$ & $4.67 \mathrm{a}$ & $105.2 \mathrm{a}$ & $11.52 \mathrm{a}$ & - \\
\hline Weed competition for 2 WFS & $8.60 b$ & $50.1 \mathrm{c}$ & $18.7 \mathrm{c}$ & $4.07 \mathrm{~b}$ & $36.83 \mathrm{e}$ & $9.54 \mathrm{~d}$ & 17.2 \\
\hline Weed competition for 4 WFS & $7.73 c$ & $38.3 \mathrm{e}$ & $16.0 \mathrm{e}$ & $3.67 \mathrm{~d}$ & $34.20 \mathrm{ef}$ & $8.42 \mathrm{f}$ & 26.9 \\
\hline Weed competition for 6 WFS & $6.30 \mathrm{~d}$ & $34.4 \mathrm{f}$ & $15.2 \mathrm{~g}$ & $2.93 \mathrm{f}$ & $28.07 \mathrm{~g}$ & $7.68 \mathrm{~g}$ & 33.3 \\
\hline Weed competition for 8 WFS & $5.63 \mathrm{e}$ & $31.0 \mathrm{~g}$ & $12.3 \mathrm{~h}$ & $2.57 \mathrm{~g}$ & $22.03 \mathrm{~h}$ & $7.13 \mathrm{~h}$ & 38.1 \\
\hline Weed competition for 10 WFS & $5.23 \mathrm{e}$ & $24.8 \mathrm{i}$ & $9.7 \mathrm{j}$ & $2.00 \mathrm{~h}$ & $14.93 \mathrm{i}$ & $6.56 \mathrm{i}$ & 43.1 \\
\hline Weed competition for whole season & $4.47 \mathrm{f}$ & $22.9 \mathrm{j}$ & $8.5 \mathrm{k}$ & $1.40 \mathrm{i}$ & $11.37 \mathrm{j}$ & $6.17 \mathrm{j}$ & 46.4 \\
\hline
\end{tabular}

Values within the same column followed by the same letters are not statistical significantly difference at $5 \%$ level Duncan's multiple range test

\section{Estimation the critical period (CP) for weed} competition in carrot fields:

According to Cousen (1991) there are two approaches to determine the critical period of weed competition to any crop: -

1 - Biological approach (classical).

2 - Regression approach

\section{1-Biological approach: -}

Figure [1] show clearly that the critical period of weed competition to carrot started after two weeks obviously, the more of delay weed removal will cause more decrease in carrot yield due to weed/carrot competition which seriously intervention yield of carrot, that may be due to the 
slow of growth of carrot in the early growth and gave poor vegetative growth in one side. Evidently, weed free maintenance form sowing to 9 weeks from

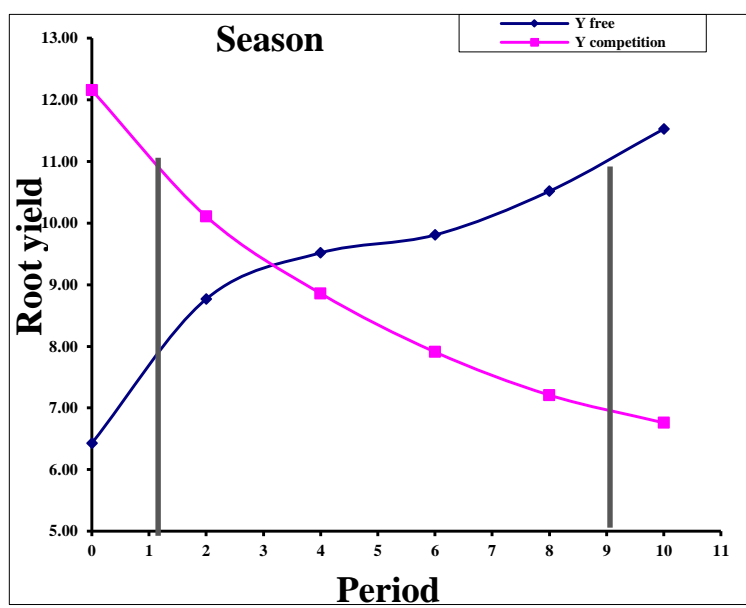

sowing is required for good yield which before and after the critical period carrot crop can be grown with weeds without losses of yield.

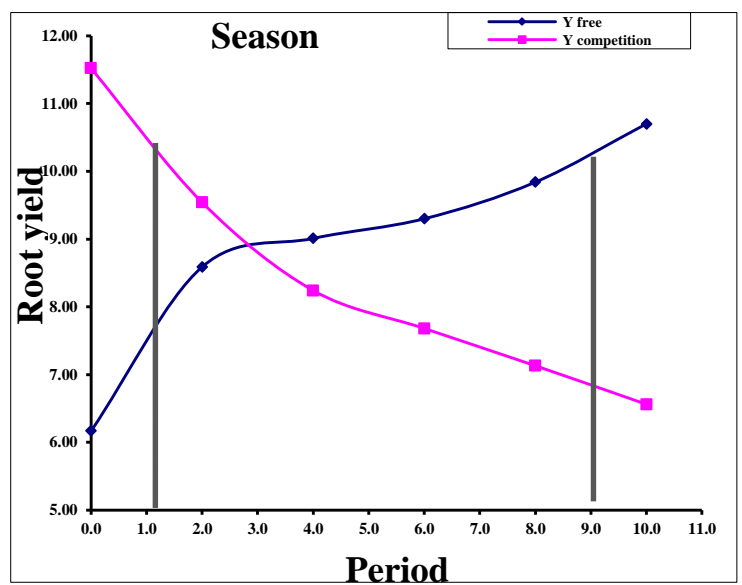

Fig (1). The critical period of weed competition for carrot yield 2016/2017 and 2017/2018 seasons.

2- Regression approach (mathematical models): -

In this approach, three mathematical models; being, linear, quadratic, and logistic models about the relationship between and carrot yield were determined as shown in Table (4). It was a clear that the suitable model which fitted for prediction yield losses or increases in carrot yield is to use quadratic equation because the correlation coefficient $\left(\mathrm{R}^{2}\right)$ was greater than linear or logistic models and standard estimate error (SE) were more smaller than they those of the mentioned models in the two seasons. The respective values of $\mathrm{R}^{2}$ and SE for non linear quadratic model were 0.92 and 0.52 for weed free period and 0.93 and 0.56 for weed competition duration in 2015 and 0.89 and 0.53 for weed free periods and0.94 and 0.43 for weed competition duration period in 2016, respectively. These results agree with El-Gizawy et. al.( 2012) and Fadlallah et. al.( 2012) they found that the suitable model which fitted for prediction yield losses or increases in cabbage and soybean yield to non linear use quadratic equation. On the other hand, critical period of weed control overall studied agricultural practices according to the recommended allowed losing yield value (10\%) being 8.3 and 8.3 weeks for weed-free and being 1.25 and 1.25 weeks for weedcompetition after sowing in 2016/17 and 2017/18, periods respectively. Root carrot yield components were declined linearly with increasing duration the mixture of weed species competition which were sensitive to weed interference and closely resembled the pattern and extent, response to carrot yield. These results agree with Mena et. al.( 1978) they found that the critical period from 1 to 60 days after emergence.

Table 4. Parameters of the three studied models of the effect of weed free or weed competition periods on yield of carrot $\left(\mathrm{kg} / \mathrm{m}^{2}\right)$ in $2016 / / 17$ and $2017 / 18$ seasons.

\begin{tabular}{|c|c|c|c|c|c|c|}
\hline Season & $\begin{array}{l}\text { Weed competition } \\
\text { Periods } \\
\end{array}$ & Modmatical & $\mathrm{R}^{2}$ & $\mathrm{SE}$ & Prediction Equation & $\begin{array}{l}\text { CPWC/ week allowed } \\
\text { losing yield (10\%) }\end{array}$ \\
\hline \multirow{6}{*}{$2016 / 2017$} & \multirow{3}{*}{ Weed-free } & Linear & 0.89 & 0.59 & & \\
\hline & & Logistic & 84 & 0.8 & & \\
\hline & & Quadratic & 0.92 & 0.52 & $Y=6.31+0.608 x-0.009 x^{2}$ & 8.3 \\
\hline & \multirow{3}{*}{ Weed competition } & Linear & 0.88 & 0.7 & & \\
\hline & & Logistic & 0.91 & 0.66 & & \\
\hline & & Quadratic & 0.93 & 0.56 & $Y=12.205-0.634 x+0.009 x^{2}$ & 1.25 \\
\hline \multirow{6}{*}{$2017 / 2018$} & \multirow{3}{*}{ Weed-free } & Linear & 0.85 & 0.6 & & \\
\hline & & Logistic & 0.8 & 0.84 & & \\
\hline & & Quadratic & 0.89 & 0.53 & $Y=6.144+0.585 x-0.007 x^{2}$ & 8.25 \\
\hline & \multirow{3}{*}{ Weed competition } & Linear & 0.9 & 58 & & \\
\hline & & Logistic & 0.92 & 0.56 & & \\
\hline & & Quadratic & 0.95 & 0.43 & $Y=11.289-0.633 x+0.009 x^{2}$ & 1.25 \\
\hline
\end{tabular}


Table 5. Estimation the expected total yield under the difference duration in 2016L2017 and 2017/2018 seasons

\begin{tabular}{|c|c|c|c|c|c|c|c|c|}
\hline \multirow{3}{*}{$\begin{array}{c}\text { Period } \\
(\text { weeks })\end{array}$} & \multicolumn{4}{|c|}{$2016 / 2017$} & \multicolumn{4}{|c|}{$2017 / 2018$} \\
\hline & \multicolumn{2}{|c|}{ Weed free } & \multicolumn{2}{|c|}{ Weed competition } & \multicolumn{2}{|c|}{ Weed free } & \multicolumn{2}{|c|}{ Weed competition } \\
\hline & $\begin{array}{c}\text { Expected } \\
\text { yield }\end{array}$ & $\%$ & $\begin{array}{c}\text { Expected } \\
\text { yield } \\
\end{array}$ & $\%$ & $\begin{array}{c}\text { Expected } \\
\text { yield }\end{array}$ & $\%$ & $\begin{array}{c}\text { Expected } \\
\text { yield }\end{array}$ & $\%$ \\
\hline $\mathbf{0}$ & 6.31 & 51.3 & 12.21 & 100 & 6.14 & 50.5 & 11.29 & 100 \\
\hline 1 & 6.61 & 53.7 & 11.58 & 94.8 & 6.72 & 55.3 & 10.67 & 94.5 \\
\hline 2 & 7.49 & 60.8 & 10.94 & 89.5 & 7.49 & 61.59 & 10.06 & 89.1 \\
\hline 3 & 8.1 & 65.8 & 10.38 & 85.0 & 8.14 & 66.9 & 9.47 & 83.9 \\
\hline 4 & 8.59 & 69.8 & 9.81 & 80.3 & 8.76 & 72.0 & 8.9 & 78.8 \\
\hline 5 & 9.13 & 74.2 & 9.26 & 75.8 & 8.9 & 73.2 & 8.35 & 74.0 \\
\hline 6 & 9.64 & 78.3 & 8.72 & 71.4 & 9.4 & 77.3 & 7.82 & 69.3 \\
\hline 7 & 10.13 & 82.3 & 8.2 & 67.2 & 9.9 & 81.4 & 7.3 & 64.7 \\
\hline 8 & 10.6 & 86.1 & 7.71 & 63.1 & 10.38 & 85.4 & 6.8 & 60.2 \\
\hline 9 & 10.98 & 89.2 & 7.23 & 59.2 & 10.85 & 89.2 & 6.32 & 56.0 \\
\hline 10 & 11.49 & 93.3 & 6.77 & 55.4 & 11.29 & 92.8 & 5.85 & 51.8 \\
\hline 11 & 11.91 & 96.8 & 6.32 & 51.8 & 11.64 & 95.7 & 5.41 & 47.9 \\
\hline 12 & 12.31 & 100 & 5.89 & 48.2 & 12.16 & 100 & 4.99 & 4.2 \\
\hline
\end{tabular}

II- Second study: The effect of weed control treatments on weeds and carrot yield and its component.

a - On weeds

The most predominant weed flora in the four field trials during 2016/17, 2017/18 and 2010/11 winter seasons were Portulaca oleracea L.; Sonchus oleraceus L.; Chenopodum album L.; Bidens bipinnata L.; Amaranthus ascendenss lois; Xanthium strumarium L.. and Malva parviflora L. as annual broad-leaved weeds with infestation

rates 0.6 and 0.85 ton dry weight ./fed in first and second seasons, respectively.

Meanwhile, Echinochloa colonum L.; Brachiaria reptans L.; Phalaris minor L. and Setaria viridis L . as annual grassy weeds with infestation rates 0.31 and 0.36 ton dry weight ./fed. in first and second seasons, respectively.

It was noticed that all herbicidal treatments and hand weeding exerted significant reduction percentage on the dry weight of presented weeds in both seasons. Ultra afalon at $500 \mathrm{~cm} 3 /$ fed. reduced broad leaf, grassy and their total weight by $93.5,94.7$ and $94.3 \%$, respectively, in the first season, and 93.3, 94.8 and $94.4 \%$,respectively, in the second season. Stomp application at $1.7 \mathrm{l} / \mathrm{fed}$. gave the followed reducing of the previous respective weeds by 93.4, 93.2.and $93.3 \%$ in the first season, and 93.3, 94.6 and $94.2 \%$ in the second season. While the efficacies of the rest of the weed control methods were in descending order as follows: Gessagard at 1.25 1/fed., Sencor at 100 $\mathrm{g} / \mathrm{fed}$., Amex at $2.5 \mathrm{l} / \mathrm{fed}$. and hand weeding twice times compared to untreated (control) in both seasons.

\section{b - On carrot yield and its components}

In table (7), the above results on controlling weeds reflected on increasing the carrot yield and its components with significant effect on both seasons. Increasing percentages of the yield carrot/fed. was obtained by the following treatments in descending order : Ultra afalon at $500 \mathrm{~cm} 3 /$ fed. By (42.1 and $44.3 \%$ ), Stomp at 1.7 1/fed (38.9 and 37.3\%), Gessagard at 1.25 1/fed. (34.9 and 31.4\%), Amex at 2.51/fed. (29.8 and $29.0 \%$ ) Sencor at $100 \mathrm{~g} / \mathrm{fed}$. (26.2 and $25.3 \%$ ) and hand weeding twice (25.2 and $23.9 \%)$, respectively, compared to unweeded check in the first and second seasons. Actually, the same trend of the above findings and the same arrangement of the treatments were observed with significant effect on carrot components i.e. No. of leaves/plant, plant height $(\mathrm{cm})$, root length $(\mathrm{cm})$, root diameter $(\mathrm{cm})$ and. root weight $(\mathrm{cm})$. That was true in both seasons. These results agree with Bakhshish Singh et. al. (2010) and Bianco (1977) they found that very good results on controlling weeds were obtained with linuron at 2 $\mathrm{kg} / \mathrm{has}$ pre-em. and butralin gave selective control of annual grasses and some broad-leaved weeds. Pendimethalin at $0.375,0.562$ and $0.750 \mathrm{~kg}$ ha and, two hand hoeing (20 and 40 days after sowing) reduced the weed dry matter accumulation significantly as compared to unweeded control. The season long weed competition reduced the carrot root yield from 11.5 to 26.1 per cent. as compared to unweeded check. 
Table 6. Effect of weed control treatments on dry weight of grassy and broadleaf and total annual weeds in g./m2 during 2016//17 and 2017/18 seasons.

\begin{tabular}{|c|c|c|c|c|c|c|c|c|c|}
\hline \multicolumn{10}{|c|}{ The dry weight of the annual weeds $\left(\mathrm{g} / \mathrm{m}^{2}\right)$} \\
\hline Season & & & & 2016 & $/ 17$ & & & & $2017 / 18$ \\
\hline $\begin{array}{l}\text { Characteristics } \\
\text { Weed } \\
\text { control } \\
\text { treatments } \\
\text { Rate /fed. }\end{array}$ & $\begin{array}{c}\text { Time of } \\
\text { application }\end{array}$ & $\begin{array}{l}\text { Grassy } \\
\text { weeds }\end{array}$ & $\begin{array}{c}\text { Red. } \\
\%\end{array}$ & $\begin{array}{c}\text { Broad } \\
\text { leaf } \\
\text { weeds }\end{array}$ & $\underset{\%}{\text { Red. }}$ & $\begin{array}{c}\text { Total } \\
\text { weeds }\end{array}$ & Red.\% & $\begin{array}{l}\text { Grassy Red. } \\
\text { Weeds } \%\end{array}$ & $\begin{array}{l}\text { Broad Red. Total Red. } \\
\text { leaf } \% \text { weeds } \% \\
\text { weeds }\end{array}$ \\
\hline Sencor at $100 \mathrm{~g}$ & Post sowing & $5.6 \mathrm{c}$ & 92.5 & $11.0 \mathrm{c}$ & 92.3 & $16.6 \mathrm{c}$ & 92.3 & $6.7 \mathrm{c}$ & 13.7c $93.220 .3 \mathrm{c} 92.9$ \\
\hline Ultra afalon at $500 \mathrm{~cm} 3$ & Post sowing & $4.8 \mathrm{c}$ & 93.5 & $7.5 \mathrm{~d}$ & 94.7 & $12.3 \mathrm{~d}$ & 94.3 & $5.7 \mathrm{c} \quad 93.3$ & $10.5 \mathrm{c} 94.816 .2 \mathrm{~d} 94.4$ \\
\hline Stomp at $1.7 \mathrm{~L}$ & Post sowing & $4.9 \mathrm{c}$ & 93.4 & $9.7 \mathrm{~cd}$ & 93.2 & $14.6 \mathrm{~cd}$ & 93.3 & $5.7 \mathrm{c} \quad 93.3$ & $10.8 \mathrm{c} 94.616 .6 \mathrm{~d} 94.2$ \\
\hline Amex at $2.5 \mathrm{~L}$ & Post sowing & $6.1 \mathrm{c}$ & 91.8 & $11.0 \mathrm{c}$ & 92.3 & $17.1 \mathrm{c}$ & 92.1 & $6.7 \mathrm{c} \quad 92.1$ & $13.5 \mathrm{c} 93.320 .2 \mathrm{c} 93$ \\
\hline Gessagard at $1.25 \mathrm{~L}$ & Post sowing & $5.1 \mathrm{c}$ & 93.1 & $9.9 \mathrm{~cd}$ & 93 & $15.0 \mathrm{~cd}$ & 93.1 & $6.2 \mathrm{c} \quad 92.6$ & 11.1c $94.517 .3 \mathrm{~cd} 94$ \\
\hline Hand weeding twice & - & $12.8 \mathrm{~b}$ & 82.8 & $25.1 b$ & 82.3 & $37.9 b$ & 82.5 & $22.9 b \quad 73$ & $\begin{array}{llll}36.1 b & 82.2 & 59.0 b & 79.4\end{array}$ \\
\hline Control & - & $74.3 \mathrm{a}$ & - & $142.2 \mathrm{a}$ & - & $216.5 \mathrm{a}$ & - & $84.8 \mathrm{a}$ & $287.7 \mathrm{a}$ \\
\hline
\end{tabular}

Values within the same column followed by the same letters are not statistical significantly difference at 5\% level Duncan's multiple range test.

Table 7. Effect of weed control treatments on growth characters at harvest during2016//17 and 2017/18 seasons.

\begin{tabular}{|c|c|c|c|c|c|c|c|c|}
\hline $\begin{array}{l}\text { Weed control Characteristics } \\
\text { treatments } \\
\text { Rate /fed. }\end{array}$ & $\begin{array}{c}\text { Time of } \\
\text { application }\end{array}$ & $\begin{array}{l}\text { No. of } \\
\text { leaves } \\
\text { /plant }\end{array}$ & $\begin{array}{l}\text { Plant } \\
\text { height } \\
(\mathrm{cm})\end{array}$ & $\begin{array}{l}\text { Root } \\
\text { length } \\
(\mathrm{cm})\end{array}$ & $\begin{array}{l}\text { Root } \\
\text { diameter } \\
(\mathrm{cm})\end{array}$ & $\begin{array}{c}\text { Root } \\
\text { weight } \\
\text { (g) }\end{array}$ & $\begin{array}{l}\text { Root } \\
\text { Yield } \\
\text { (t/fed) }\end{array}$ & $\begin{array}{c}\text { Reduction } \\
\text { yield \% } \\
\text { from weed } \\
\text { free }\end{array}$ \\
\hline & \multicolumn{8}{|c|}{ 2016/17season } \\
\hline Sencor at $100 \mathrm{~g}$ & Post sowing & $8.60 \mathrm{c}$ & $37.3 b-d$ & $21.5 b$ & $3.9 \mathrm{~b}$ & $106.3 c$ & $12.33 \mathrm{c}$ & 26.2 \\
\hline Ultra afalon at $500 \mathrm{~cm}$ & Post sowing & $10.73 a$ & $41.5 \mathrm{a}$ & $26.7 \mathrm{a}$ & $4.8 \mathrm{a}$ & $113.7 \mathrm{a}$ & $13.88 \mathrm{a}$ & 42.1 \\
\hline Stomp at $1.7 \mathrm{~L}$ & Post sowing & $9.87 \mathrm{ab}$ & $39.5 \mathrm{ab}$ & $25.4 \mathrm{a}$ & $4.5 \mathrm{a}$ & $111.1 \mathrm{ab}$ & $13.52 \mathrm{ab}$ & 38.9 \\
\hline Amex at $2.5 \mathrm{~L}$ & Post sowing & $9.53 b c$ & $36.5 \mathrm{~cd}$ & $21.7 \mathrm{~b}$ & $4.0 \mathrm{~b}$ & $107.2 \mathrm{bc}$ & $12.68 \mathrm{c}$ & 29.8 \\
\hline Gessagard at $1.25 \mathrm{~L}$ & Post sowing & $9.40 \mathrm{bc}$ & $38.1 \mathrm{bc}$ & $25.6 \mathrm{a}$ & $4.1 b$ & $108.9 \mathrm{bc}$ & $13.18 b$ & 34.9 \\
\hline Hand weeding twice & - & $8.53 \mathrm{c}$ & $34.9 \mathrm{~d}$ & $20.4 b$ & $3.7 b$ & $93.5 \mathrm{~d}$ & $12.23 \mathrm{c}$ & 25.2 \\
\hline \multirow[t]{2}{*}{ Control } & - & $6.47 \mathrm{~d}$ & $26.4 \mathrm{e}$ & $16.9 \mathrm{c}$ & $2.7 \mathrm{c}$ & $55.9 \mathrm{e}$ & $9.77 \mathrm{~d}$ & - \\
\hline & \multicolumn{8}{|c|}{$2017 / 18$ season } \\
\hline Sencor at $100 \mathrm{~g}$ & Post sowing & $7.70 \mathrm{~cd}$ & $33.6 \mathrm{c}$ & $22.1 \mathrm{c}$ & $3.9 b c$ & $102.7 \mathrm{c}$ & $11.97 \mathrm{c}$ & 25.3 \\
\hline Ultra afalon at $500 \mathrm{~cm} 3$ & Post sowing & $9.47 \mathrm{a}$ & $40.3 a$ & $26.2 \mathrm{a}$ & $4.4 \mathrm{a}$ & $110.6 a$ & $13.78 \mathrm{a}$ & 44.3 \\
\hline Stomp at $1.7 \mathrm{~L}$ & Post sowing & $9.20 \mathrm{a}$ & $38.1 \mathrm{ab}$ & $25.6 a b$ & $4.2 \mathrm{ab}$ & $109.0 \mathrm{ab}$ & $13.11 b$ & 37.3 \\
\hline Amex at $2.5 \mathrm{~L}$ & Post sowing & $8.20 \mathrm{bc}$ & $33.8 \mathrm{c}$ & $23.2 \mathrm{c}$ & $3.9 \mathrm{bc}$ & $104.3 b c$ & $12.32 \mathrm{c}$ & 29 \\
\hline Gessagard at $1.25 \mathrm{~L}$ & Post sowing & $8.47 b$ & $37.0 \mathrm{~b}$ & $24.5 b$ & $4.0 \mathrm{ab}$ & $107.3 \mathrm{a}-\mathrm{c}$ & $12.55 \mathrm{ab}$ & 31.4 \\
\hline Hand weeding twice & - & $7.40 \mathrm{~d}$ & $32.8 \mathrm{c}$ & 20. $0 \mathrm{~d}$ & $3.5 \mathrm{c}$ & $91.9 \mathrm{~d}$ & $11.83 \mathrm{c}$ & 23.9 \\
\hline Control & - & $6.33 \mathrm{e}$ & $23.7 \mathrm{~d}$ & $16.3 \mathrm{e}$ & $2.4 \mathrm{~d}$ & $55.20 \mathrm{e}$ & $9.55 \mathrm{~d}$ & - \\
\hline
\end{tabular}

Values within the same column followed by the same letters are not statistical significantly difference at 5\% level Duncan's multiple range test

\section{Herbicidal residues determination}

From Figs (2-11) and (Table, 8) the Gas Liquid Chromatography was used to detected the applied herbicides on carrot roots showed no signal to five herbicidal used (not detected). These five herbicides used (pendimethalin, butralin, metribuzin, prometryn and linuron) degraded in the carrot plants and the GLC couldn't read any values. The residues level of the these herbicides depended on the nature of plant.
Moreover, some herbicides were rapidly degraded in open field by sunlight and its stability in soil which have many species of microorganisms any fertilizers and different level of acidity and alkalinity in addition the hoeing of the soil. These results agree with those obtained by Bakhshish Singh et. al. (2010) who found that the residues of pendimethalin was below detectable level in this study. 
Table 8. Pendimethalin, butralin, metribuzin, prometryn and linuron Residues in carrot roots at harvest

\begin{tabular}{|l|c|c|}
\hline Herbicides name & Residual (ppm) & Max.Residue Level[mg/kg] \\
\hline Pendimethalin & N D & 0.02 \\
Butralin & N D & 0.01 \\
Metribuzin & N D & 0.01 \\
Prometryn & N D & 0.5 \\
Linuron & N D & 0.5 \\
\hline
\end{tabular}

ND $=$ Not detected

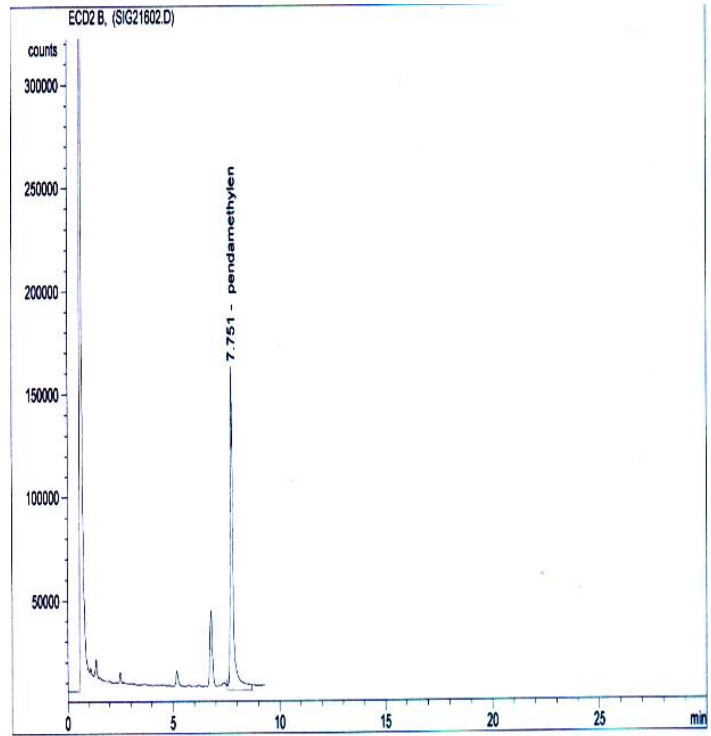

Fig (2) : standard of Pendimethalin

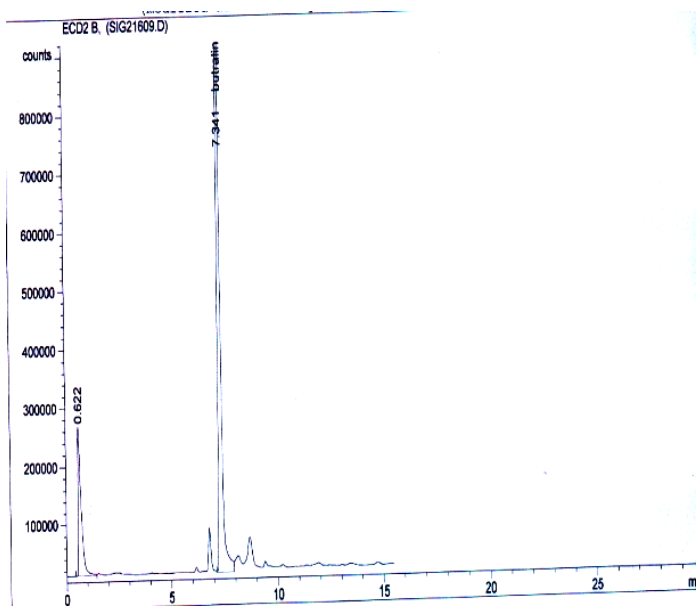

Fig (4) : standard of butralin

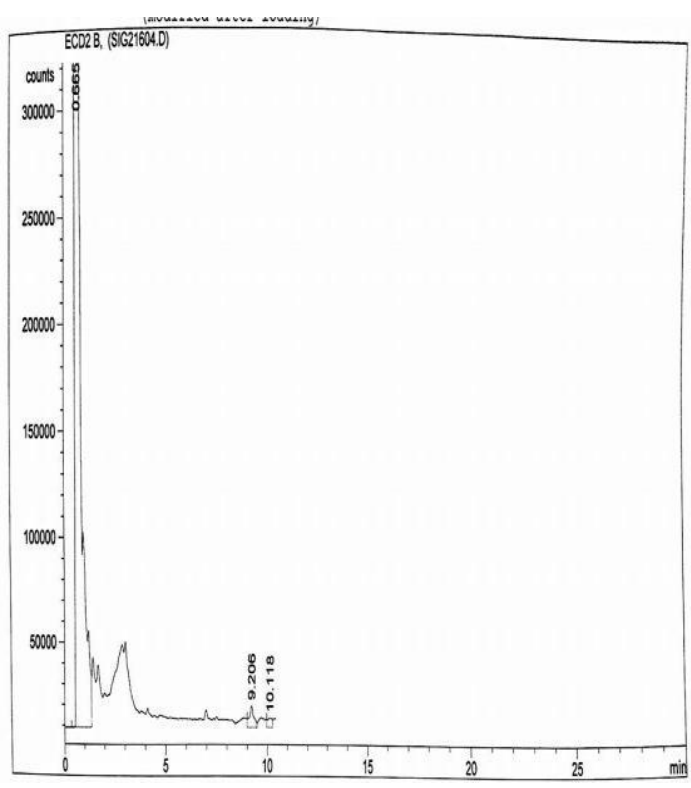

Fig (3) : sample of Pendimethalin

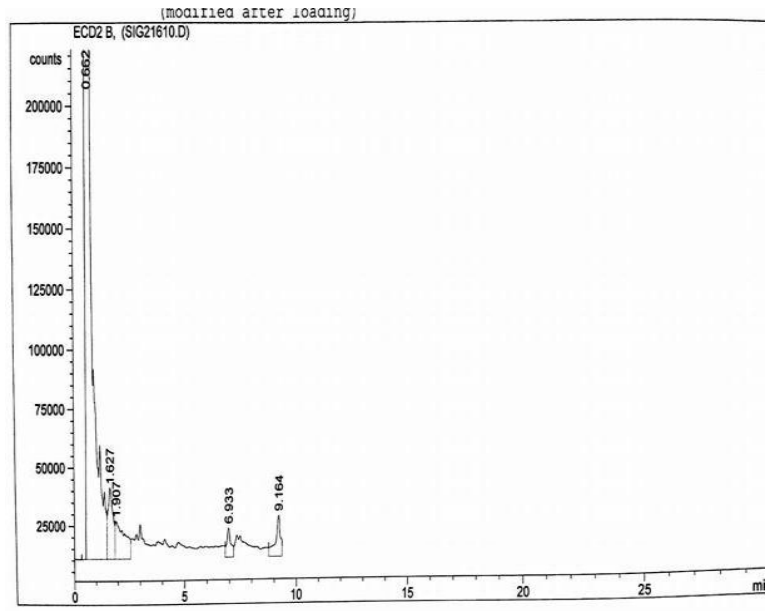

Fig (5) : sample of butralin 

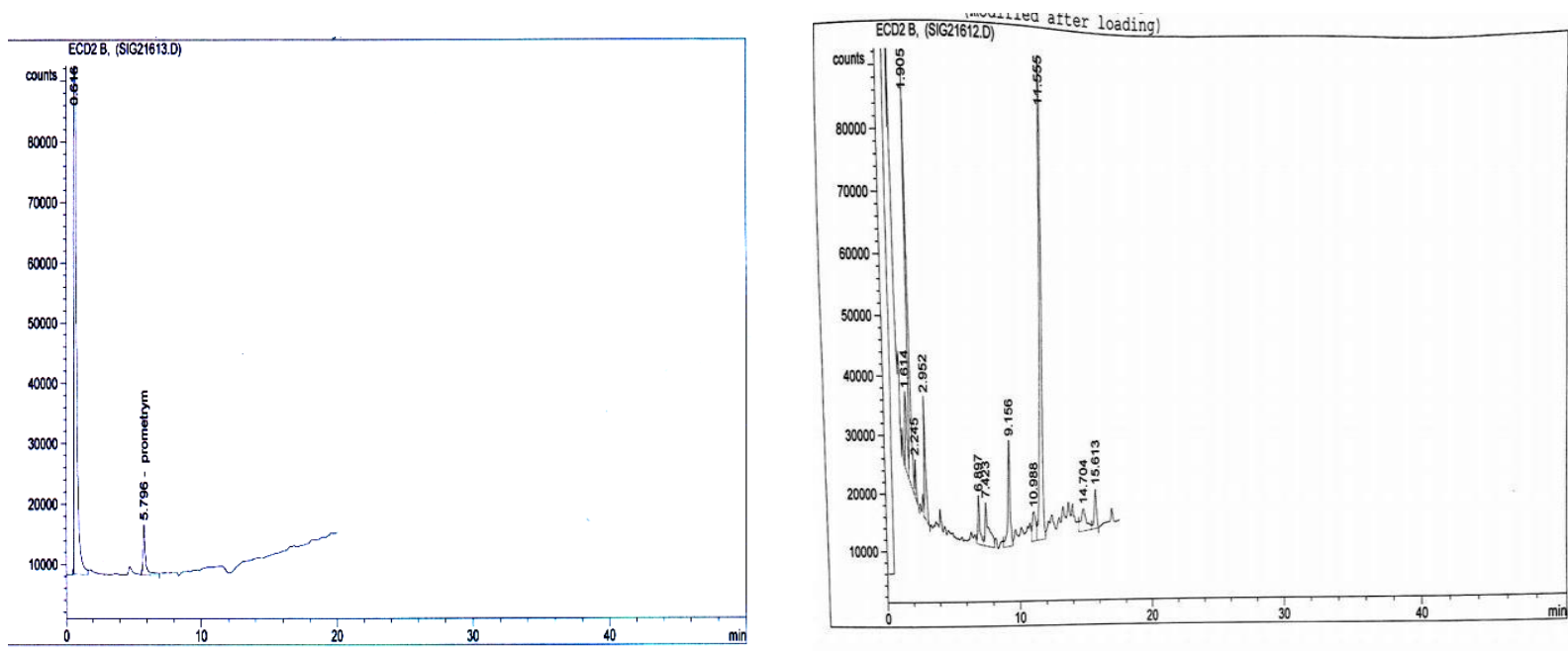

Fig (6) : standard of prometryn

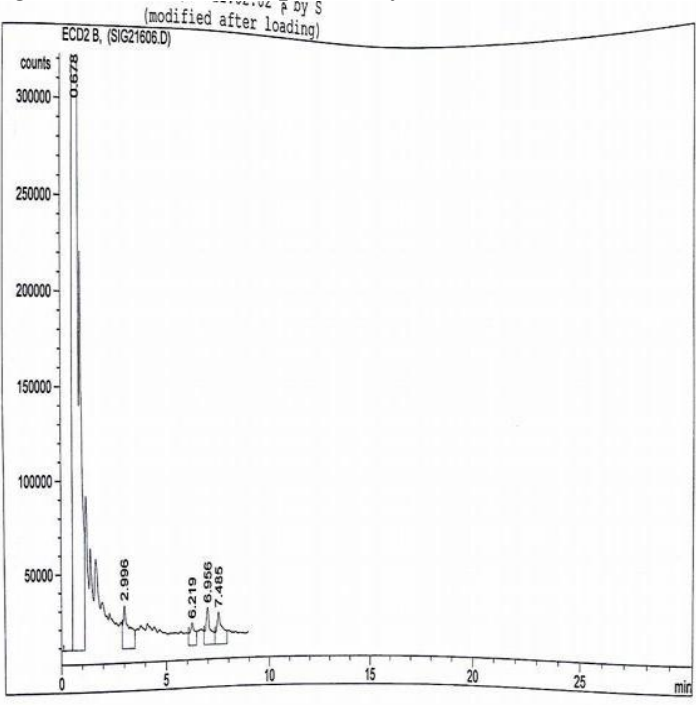

Fig (7) : sample of prometryn

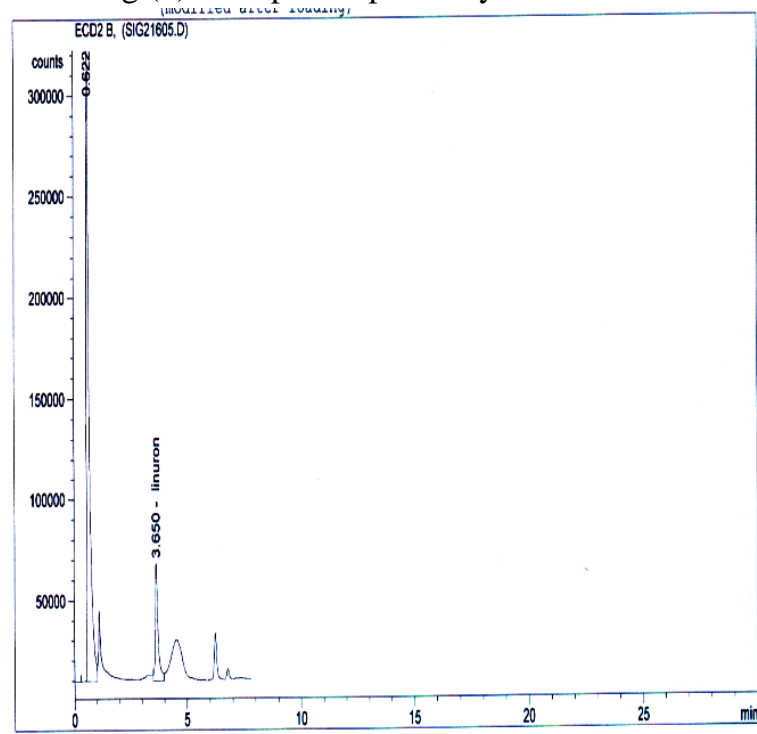

Fig (8): standard of linuron

Fig (9) : sample of linuron
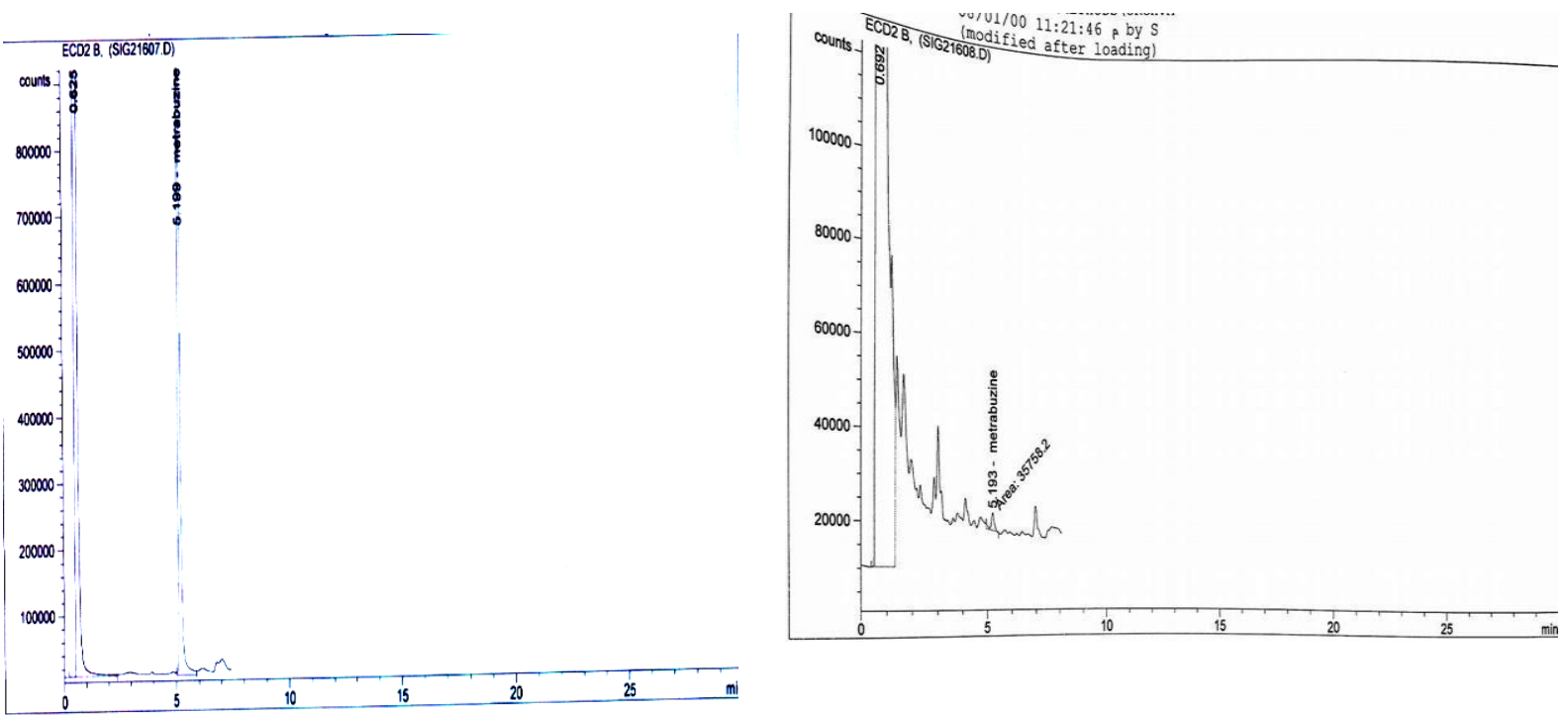

Fig (10): standard of metribuzin

Fig (11): samples of metribuzin 
Economic feasibility for weed control in carrot. Economic evaluation in Table (9) showed hat increasing the profitability was with Ultra afalon at $500 \mathrm{~cm}^{3}$ /fed. (1.99 and 1.83) at the top and hand hoeing twice at the foot of (1.63 and 1.44 , respectively, in both seasons. The rest of treatments were arranged according to increase profitability as follows Stomp at 1.71 /fed. Gessagard at $1.25 \mathrm{l} / \mathrm{fed}$., Sencor at $100 \mathrm{~g} / \mathrm{fed}$ and Amex at 2.5 1/fed., respectively.

Table 9. Determination economic for weed control in carrot during 2016//17 and 2017/18 seasons.

\begin{tabular}{|c|c|c|c|c|c|c|}
\hline \multirow[b]{2}{*}{$\begin{array}{l}\text { Weed Control } \\
\text { Treatments } \\
\text { Rate /fed. } \\
\end{array}$} & \multirow[b]{2}{*}{ Time of application } & \multirow[b]{2}{*}{$\begin{array}{c}\text { Yield } \\
\text { (ton /fed.) }\end{array}$} & \multirow[b]{2}{*}{$\begin{array}{l}\text { Total cost } \\
\text { L.E. }\end{array}$} & \multirow[b]{2}{*}{$\begin{array}{c}\text { Gross } \\
\text { income } \\
\text { L.E. }\end{array}$} & \multirow[b]{2}{*}{$\begin{array}{l}\text { benefit } \\
\text { L.E. }\end{array}$} & \multirow[b]{2}{*}{$\begin{array}{c}\text { Benefit } \\
\text { /Cost }\end{array}$} \\
\hline & & & & & & \\
\hline & \multicolumn{6}{|c|}{$2016 / 17$ season } \\
\hline Sencor at $100 \mathrm{~g}$ & Post sowing & $12.33 \mathrm{c}$ & 13403 & 24660 & 11230 & 1.84 \\
\hline Ultra afalon at $500 \mathrm{~cm}^{3}$ & Post sowing & $13.88 \mathrm{a}$ & 13.480 & 27760 & 14280 & 1.99 \\
\hline Stomp at $1.7 \mathrm{~L}$ & Post sowing & $13.52 \mathrm{ab}$ & 13710 & 27040 & 13330 & 1.97 \\
\hline Amex at $2.5 \mathrm{~L}$ & Post sowing & $12.68 \mathrm{c}$ & 13900 & 25360 & 11460 & 1.82 \\
\hline Gessagard at $1.25 \mathrm{~L}$ & Post sowing & $13.18 b$ & 13550 & 26360 & 12810 & 1.94 \\
\hline Hand weeding twice & - & $12.23 \mathrm{c}$ & 14530 & 24460 & 9930 & 1.68 \\
\hline \multirow{2}{*}{ Control } & - & $9.77 \mathrm{~d}$ & 13400 & 19540 & 6140 & 1.45 \\
\hline & \multicolumn{6}{|c|}{$2017 / 18$ season } \\
\hline Sencor at $100 \mathrm{~g}$ & Post sowing & $11.97 \mathrm{c}$ & 16930 & 26930 & 10000 & 1.59 \\
\hline Ultra afalon at $500 \mathrm{~cm}^{3}$ & Post sowing & $13.78 \mathrm{a}$ & 16980 & 3100 & 14020 & 1.83 \\
\hline Stomp at $1.7 \mathrm{~L}$ & Post sowing & $13.11 \mathrm{~b}$ & 17210 & 29490 & 12280 & 1.71 \\
\hline Amex at $2.5 \mathrm{~L}$ & Post sowing & $12.32 \mathrm{c}$ & 17400 & 27720 & 10320 & 1.59 \\
\hline Gessagard at $1.25 \mathrm{~L}$ & Post sowing & $12.55 \mathrm{ab}$ & 17050 & 28230 & 11180 & 1.65 \\
\hline Hand weeding twice & - & $11.83 \mathrm{c}$ & 18400 & 26620 & 8220 & 1.44 \\
\hline Control & - & $9.55 \mathrm{~d}$ & 16900 & 2.480 & 4580 & 1.27 \\
\hline
\end{tabular}

Values within the same column followed by the same letters are not statistical significantly difference at 5\% level Duncan's multiple range test

\section{Conclusion}

We can conclude from the present work that nine weeks from carrot sowing were required to kept carrot yields free to obtaine maximum yield and/or one week of weed competition without damage. Ultra afalon at $500 \mathrm{~cm}^{3} / \mathrm{fed}$., Stomp at $1.71 /$ fed. and Gessagard at $1.25 \mathrm{l} / \mathrm{fed}$. herbicides gave the best used control of annual weeds accompanied with the highest root yield of carrot and there no any residual effect for all herbicides under this study in carrot root. So we can be recommended these herbicides for control weeds in carrot and economically feasibility carrot growers in Egypts .

\section{References}

Agresti, Alan (1996). An introduction to categorical Data Analysis. John Wiley and Sons, Inc.

Arcuset, P.; Berengier, J.; Rabourdin, C.; Sergent, G.(1977). Mixture of butralin and linuron for weed control in carrots. [French] Compte Rendu de la 9e Conference du COLUMA.;. 690-698. 2 ref.

Bakhshish Singh; Bhullar, M. S.; Walia, U. S.; Randhawa, S. K.; Phutela, R. P.(2010). Weed control in carrot (Daucas carota L.): bio-efficacy and residues of pre-emergence herbicides. Indian Journal of Ecology;. 37(2):145-148.
Coelho, M.; Bianco, S.; Carvalho, L. B.(2009). Weed interference on carrot crop (Daucus carota). [Portuguese] Planta Daninha;. 27(Especial):913920. 26 ref.

Cousen, R. (1991) Aspects of the design and interpretation of competition (interference) experiments. Weed Techn. 5:664 - 673.

Everman, W. I.; S. B. Clewis; W. E. Thomas; I. Burk and W. J. Wilcut (2008) Critical period of weed interference in peanut. Weed Techn., 22:6367.

Fadlallah, A. M. 1 Hassanein, A. M. A. 1 Hatem, M. K. 2(2012).Effect of weed competition and its control methods on growth, residues and yield of (Brassica oleracea var capitata) Proc. 13th international Conf. Agron.,Fac.of Agic., Benha Univ., Egypt, pp. 1- 14.

Farag, I. A.; Hussein, H. A.; Farghali, M. A.(2001). Effect of chemical weed control on growth of weeds, yield and quality of carrot. Haryana Journal of Horticultural Sciences; 30(1/2):116120.

Freitas, F. C. L.; Almeida, M. E. L.; Negreiros, M. Z.; Honorato, A. R. F.; Mesquita,H. C.; Silva, S. V. O. F.(2009). Periods of weed interference in carrot in function of spacing between rows. [Portuguese] Planta Daninha;. 27(3):473-480. 27 ref. 
Gomez, K. A. and A. A. Gomez (1984). Statistical procedures for agricultural research. John Wiley \& Sons, Inc. New York, USA.

Hall, M. R.; C. J. Swanton and G. W. Anderson (1992). The critical period of weed control in grain corn (Zea mays). Weed Sci. 40: 441-447.

Heady, E. O. and J.L. Dillon, (1961). Agricultural production functions. Library of congress catalog card number: $60-11128$, Iowa State University press.

Jackson, M. L. (1967): Soil Chemical Analysis. Prentice - Hall of India Private Limated, New Delhi.

Kavaliauskaite, D.; Starkute, R.; Bundiniene, O.; Jankauskiene, J. (2009). Chemical weed control in carrot crop. Acta Horticulturae;. (830):385390.

Knezevic, S. Z.; S. P. Evans and M. Mainz (2003). Row spacing influences the critical timing for weed removal in soybean (Glycine max). Weed

Konstantinov, K.; Vuchev, S.(1977). Weed control in vegetable crops. [Bulgarian] Rastitelna Zashchita;. 25(4):10-13.

Kropf, U.J. and Vanlaar ,H.H.(1993). Modeling crop-weed interactions. Walling ford, UK. CAB. International, P. 137- 147.

Mena, F.; Madronero, E.; Salcedo-Z., A.; CriolloE., H.( 1978). A study of the critical period of competition between weeds and carrot (Daucus carota L.) crops on the Pasto plateau, Narino Department. [Spanish]. Revista de Ciencias Agricolas;. 8(1/14):114-120.

Moenandir, J. (1987). Critical period of carrot (Daucus carota) due to existence of weeds in East Java. Proceedings, 11th Asian Pacific Weed Science Society Conference.;. (2):507-510.

Montemurro, P.; Bianco, V. V.( 1977). Experiments for weed control in carrots. [Italian] Atti: Stato Attuale della Lotta alle Malerbe nelle Colture Arboree, Ortofloricole e Cerealicole, Bologna,.; 1977. 183-189.
El-Gizawy, N. Kh. B.; Fadlallah, A. M.; Hassanein, A. M. A. and Soliman, I. E. (2012). Estimation of the critical period for weed control in soybean (Glycine max L) as influenced plant density J. Plant Production, Mansoura Univ., Vol. 3 (9): 2375 - 2394,

Neter, J.; W. Wasserman and M. H. Kunter (1990). Applied linear statistical models $3^{\text {rd }}$ ed., IRWIN, Homewood, Boston, U.S.A.

Nguyen T.D., Han E. M., Seo M.S., Kim S.R.Yun M.Y., Lee D.M. and Lee, G.H. (2008). Amultiresidue method for the determination of 204 pesticides in rice paddies using gas chromatography/mass spectrometry. Analy. Chem. Acta, 619: 67-74.

Nieto, J.H.;M.A.Brando and J.T. Gonzales (1968). Critical period of the crop growth cycle for competition from weeds .Pest. Artic.Summ.14:1

Norsworthy, J. K. and M. J. Oliverira (2004). Comparison of the critical period for weed control in wide and narrow row corn. Weed Sci. 52: 802807.

Piper, C. S. (1950): Soil and Plant Analysis. Inter. Science Publ. INC., New York.

Richardson, W. G.; West, T. M.; 777777Parker, C (1979). The activity of pre-emergence selectivity of some recently developed herbicides: R 40244, AC 206784, pendimethalin, butralin, acifluorfen and FMC 39821.Technical Report, Agricultural Research Council, Weed Research Organization;. (57):71 pp.

Swanton, C. J. and Wise, S.F. (1991). Integrated weed management: the rational and approach. Weed Technology, 5: 657-663.

Zimdahl, R. L. (1988). The concept and application of the critical weed free period. In Altieri, M.A \& Liebmann, M., eds. Weed Management in Agroeco system: Ecological Aproaches . PP 145 155 CRS Press. Boca Roton . Florida, USA. 


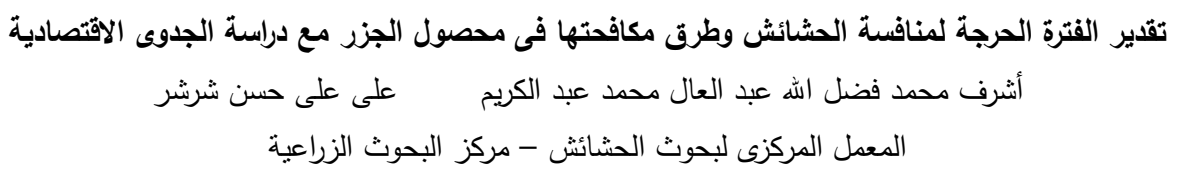

أجريت دراستين (أربعة تجارب حقلية) فى تربة طينية بمحطة بحوث البساتين بالقناطر الخيرية بمحافظة القليوبية خلا موسمى

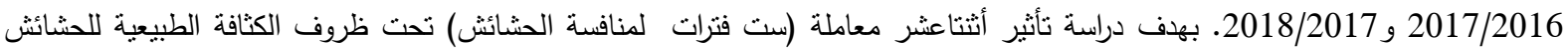

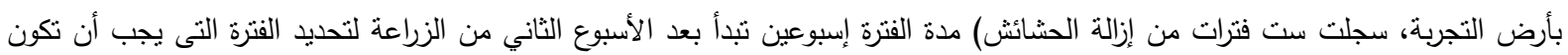

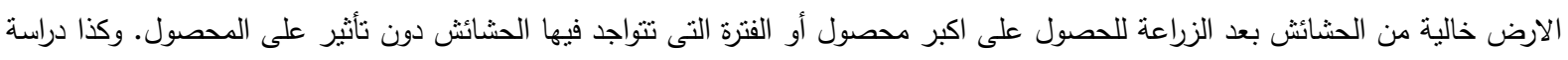

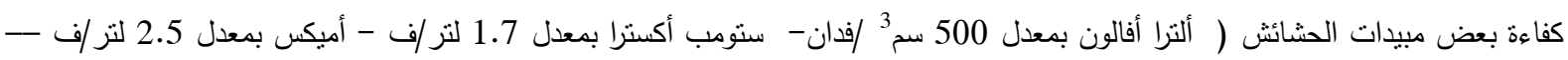

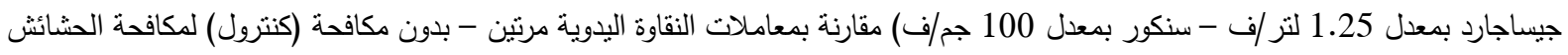
الحولية المصاحبة لمحصول الجزر • وأثر ذلك علي المحصول ومكوناته. أوضحت النتائج فى الدراسة الأولى أن كثافة الحشائش في معاملة المقارنة (ترك الحشائش طوال الموسم ) قدرت بحوالي 1.44 ، 2.04 طن/ف مادة جافة والتي أحدثت نقصا في محصول جذور الجزر بمقدار 47.1 ، 4 ، 47\% عند نزك الحشائش مقارنة بمعاملات أزالة الحشائش طوال الموسم فى موسمي الزراعة على التوالى .كما أوضحت دراسة العلاقة بين فترات

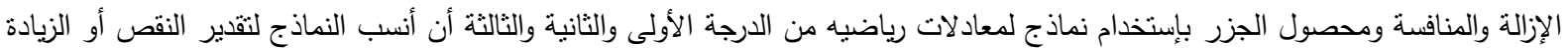

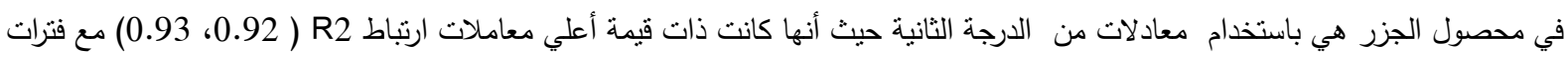
الإزالة WF و (0.89، 0.94) مع فترات المنافسة WC وأقل في الإنحراف القياسي (SE) في الموسمين ، مقارنة بالنموذجين الآخرين • ومن خلال المعادلات الرياضية بمكن القبول بأنة يمكن للحصول على 90\% من المحصول وذللك لفترة ازالة حشائش تتراوح بين 8.3 \& 8.25 أسبوع • أو ترك الحشائش لفترة 1.25 أسبوع من بداية الزراعة فى كلا الموسمين. بينما أوضح نطبيق النموذج البيولوجى باستخدام منحنيات العلاقة بين فترات الازالة والترك للحشائش أن الفترة الحرجة لمنافسة الحشائش لمحصول الجزر انها من الزراعة وحتى 9 أسابيع · حيث أعطت معاملة إزالة

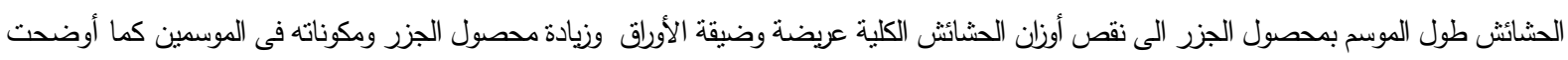
النتائج فى الدراسة الثانية أن كثافة الحشائش في معاملة المقارنة قدرت بحوالي 0.91 ، 1.21 طن/ف. لـ كما أدت طرق مكافحة الحشائش إلى نقص معنوى فى الوزن الجاف للحشائش الحولية وأعطت الترا أفالون بمعدل 500 سم³ /الفدان وستومب أكسترا بمعدل 1.7 لتر / الفدان جيساجارد بمعدل 25.لتر /الفدان أعلى انخفاض فى وزن الحشائش الحولية الكلية( عريضة وضيقة الأوراق). وأيضا أدت طرق مكافحة الحشائش إلى زيادة معنوية فى صفات المحصول ومكوناته حيثً أعطت معاملات الترا أفالون بمعدل 500 سم /الفدان وستومب أكسترا بمعدل 1.7 لتر / الفدان جيساجارد بمعدل 25. لتزر /الفدان أفضل النتائج لهذه الصفات. وعدم وجود أى أثر متبقى لجميع المبيدات تحت الدراسة.

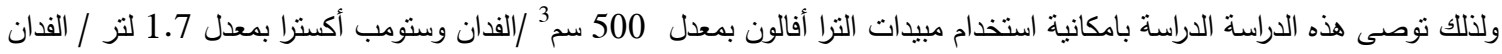
جيساجارد بمعدل 25. لنر /الفدان لمكافحة الحشاش الحولية الكلية. خلال النسع أسابيع الأولى من الزراعة وذللك خلال الفترة المؤثرة فى منافسة الحشائش للمحصول. 